\title{
KESALAHAN BERBAHASA DALAM KARANGAN DESKRIPSI \\ BERBAHASA MANDARIN MAHASISWA PRODI PENDIDIKAN
}

BAHASA MANDARIN

\author{
Rendy Aditya \\ Universitas Negeri Surabaya, aditya_frenz11@yahoo.com
}

\begin{abstract}
The approach used in this study is a qualitative approach, because this study aims to describe the linguistic fault lines in the descriptive essay done by the students of Chinese Education Department of University state of Surabaya academic year 2012. In this research, there are 53 essays written by 53 respondent. Data analysis was initiated by identifying the mistakes in syntax and lexicon of descriptive essay in Mandarin, then classify these forms of error into linguistic taxonomy, and concluded the factors that cause errors speak. The results of this study consists of three parts. The first part is finding a syntax error in the form of a descriptive essay in Mandarin, which forms a syntax error in the preparation of fungtor language of Mandarin, some 5 grains fault error. Furthermore, the use of particles in Mandarin improper, some 9 points of error. The latter syntax error is improper preparation of the sentence as much as 82 grains of error. Where errors in grammar occur due to the authors make a mistake that the order of words in reverse. In addition there is also a mistake lexicon, namely in the form of improper use of the word as much as 134 grains contained errors. The latter is a global and a local fault. Globally there are 8 points errors and locally there are 6 items mistake. Factors causing the linguistic fault lines obtained from interviews of respondents stated that when studying Mandarin, the most difficult thing to learn is the grammar. This isproved by the number of 8 respondents who answered grammar is the hardest less onto learn. Then the tone and word pronunciation difficulties as many as seven people. The latter as much as 3 respondents said things that are difficult to study in Mandarin is writing Chinese characters. Recently, there were 14 respondents who were not able to give an example of the full text of some kind of sentence filed by the researcher to the respondents.
\end{abstract}

Keywords: Mandarin language, linguistic fault, syntax

\section{PENDAHULUAN}

Bahasa Mandarin selain disebut sebagai 普通话 (putonghua). Kata Mandarin berasal dari Tiongkok yang secara harafiah merupakan sebutan 
pembesar-pembesar suku Man, yang merupakan suku minoritas pada zaman dinasti Qing. Menurut Chen (dalam Mia, 2014:5--6), penggunaan bahasa Mandarin merujuk kepada satu dialek China utara. Hal ini disebabkan di antara dialek-dialek yang ada di China penyebaran dialek ujaran Utara yang paling luas dan penduduk yang menggunakan juga paling banyak. Seiring dengan perkembangan zaman dalam hal penggunaan bahasa dalam pemerintahan dan bahasa tulis yang disebut 白话文 (bai hua wen), dialek utara ini memiliki sifat universal. Sebagai dasar dari pembentukan kosakata bahasa Mandarin modern, dialek Utara tidak serta merta langsung begitu saja digunakan, tetapi harus mengalami penyeleksian, bagian yang terlalu kuat logatnya dihilangkan dan bagian yang sesuai dengan keadaan masyarakat boleh tetap digunakan. Menurut Kridalaksana (2008: 205) Mandarin atau Putonghua adalah ragam bahasa Han yang terpenting dan terbanyak pemakainya di negeri China. Salah satu dialek yang dipakai di sekitar Beijing (Peking), menjadi dasar bahasa nasional di negeri itu. Istilah Putong hua hanya dipakai di P.R.C. Istilah yang lebih dikenal ialah Mandarin (Kridalaksana, 2008: 205).

Dalam pembelajaran bahasa Mandarin, tentu saja para pebelajar bahasa pernah melakukan kesalahan berbahasa, misalnya melakukan kesalahan sintaktis. Dalam mempelajari bahasa Mandarin, terdapat kesulitan umum yang dialami oleh pebelajar bahasa Mandarin di Indonesia. Misalnya, dalam bahasa Mandarin, ada menulis hanzi yang membutuhkan ketepatan cara dan hitungan banyaknya goresan hurufnya. Selain itu, di dalam bahasa Mandarin juga terdapat pelafalan dan nada yang harus dilafalkan secara tepat sesuai dengan nada dan pengucapan ejaannya. Jika seseorang melafalkan dengan nada dan pelafalan yang salah dapat dipastikan maksud yang ingin disampaikan akan salah juga. Menurut Tarigan (1988:199), kesalahan sintaksis adalah kesalahan atau penyimpangan struktur frasa, klausa, atau kalimat, serta ketidaktepatan pemakaian partikel. Contoh kesalahan sintaksis dalam tata bahasanya, ketika seorang pebelajar mengartikan 
sebuah kalimat ke dalam bahasa Mandarin, misalnya kalimat "Saya pergi ke Surabaya naik kereta api”. Jika mengikuti susunan tata bahasa Mandarinnya yang benar adalah 我坐火车去泗水, karena mengikuti aturan SKPO. Akan tetapi tidak sedikit pebelajar yang menuliskan 我去泗水坐火车, sehingga yang bersangkutan melakukan kesalahan dalam hal tata bahasa sebuah kalimat dalam bahasa Mandarin karena terpengaruh oleh tata bahasa B1 mereka.

Pada awal Mei 2015, peneliti melakukan uji coba awal kepada mahasiswa angkatan 2012 Prodi Pendidikan Bahasa Mandarin UNESA. Ketika itu peneliti memberikan 20 kata dalam bahasa Mandarin untuk dibuat kalimat dalam bahasa Mandarin. Hasilnya adalah 56 anak masih melakukan kesalahan dalam menyusun kalimat dengan kata-kata yang sudah diberikan. Misalnya saja, ada seorang mahasiswa yang membuat kalimat dengan kata 会 (huì) yang memiliki arti bisa 能 (neng) yang memiliki arti kata “dapat”. Mahasiswa tersebut membuat kalimat sebagai berikut, (1) 我能开车 (Wǒ neng kāichē) atau (2) 我能开车去学校 (Wǒ neng kāichē qù xuéxiào). Yang seharusnya mahasiswa tersebut menuliskan (1) 我会开车 (Wǒ huì kāichē) dan (2) 我会开车去学校 (Wǒ huì kāichē qù xuéxiào). Dari hasil tes awal ini, peneliti ingin meneliti lebih jauh lagi kesalahan sintaktis dalam karangan deskriptif mahasiswa angkatan 2012/2013 Prodi Pendidikan Bahasa Mandarin UNESA.

Peneliti memutuskan karangan deskriptif dikarenakan para mahasiswa angkatan 2012/2013 tersebut telah belajar menulis karangan deskriptif dan memiliki cukup kemampuan dalam membuat kalimat dengan menggunakan tata bahasa bahasa Mandarin. Sehingga peneliti memutuskan untuk melakukan penelitian dengan subjek para mahasiswa angkatan 2012/2013 Prodi Pendidikan Bahasa Mandarin UNESA. Dari latar belakang tersebut, peneliti ingin memfokuskan beberapa masalah yang diteliti dan melakukan penelitian dengan 
judul "Kesalahan Berbahasa dalam Karangan Deskripsi Berbahasa Mandarin Mahasiswa 2012/2013 Prodi Pendidikan Bahasa Mandarin Universitas Negeri Surabaya". Dengan mengacu pada latar belakang tersebut, penelitian ini difokuskan pada:

1) Bentuk kesalahan sintaktis dalam karangan deskripsi berbahasa Mandarin Mahasiswa angkatan 2012/2013 Prodi Pendidikan Bahasa Mandarin UNESA?

2) Bentuk kesalahan leksikon dalam karang deskripsi berbahasa Mandarin mahasiswa angkatan 2012/2013 Prodi Pendidikan Bahasa Mandarin UNESA?

3) Faktor yang menyebabkan kesalahan sintaktis pada karangan deskripsi mahasiswa angkatan 2012/2013 Prodi Pendidikan Bahasa Mandarin UNESA?

Penelitian ini menggunakan pendekatan kualitatif dengan metode deskriptif. Pada hakikatnya penelitian kualitatif yang menitikberatkan pada analisis isi, yaitu penelitian yang mementingkan pengkajian isi dengan tujuan memahami nilai-nilai yang terkandung dalam objek penelitian yang dijabarkan secara verba. Menurut Ghony dan Fauzan (2012: 25), penelitian kualitatif adalah penelitian yang menghasilkan penemuan-penemuan yang tidak dapat dicapai dengan menggunakan prosedur statistic atau dengan cara-cara kuantitatif. Penelitian kualitatif adalah penelitian yang menekankan pada quality atau hal terpenting suatu barang atau jasa. Hal terpenting suatu barang atau jasa yang berupa kejadian, fenomena, dan gejala sosial adalah makna di balik kejadian tersebut yang dapat dijadikan pelajaran berharga bagi pengembangan konsep teori.

Pendekatan yang digunakan dalam penelitian ini adalah pendekatan kualitatif. Mengingat penelitian ini mencari hasil berupa hasil deskriptif dari kesalahan sintaksis dan leksikon dalam karangan deskriptif Mandarin mahasiswa Prodi Pendidikan Bahasa Mandarin Unesa angkatan 2012, sehingga peneliti menggunakan pendekatan kualitatif. Menurut Moleong (2011:6), penelitian kualitatif adalah penelitian yang menghasilkan prosedur analisis yang tidak menggunakan prosedur analisis statistik atau cara kuantifikasi. Penelitian 
kualitatif memiliki ciri-ciri yang membedakannya dari jenis penelitian lain. Dengan pendekatan kualitatif ini, penelitian ini akan menggunakan metode deskriptif dan cenderung menggunakan analisis dengan pendekatan induktif. Pendekatan induktif adalah pendekatan dengan menggunakan data sebagai pijakan awal melakukan penelitian, bahkan dalam format induktif tidak mengenal teorisasi sama sekali. Hal ini sejalan dengan penelitian yang akan dilakukan yaitu dengan mengumpulkan data, mengklasifikasikan data tentang kesalahan sintaksis dan leksikon dalam karangan deskriptif berbahasa Mandarin mahasiswa angkatan 2012/2013 Prodi Pendidikan Bahasa Mandarin UNESA. Karena penelitian ini ingin mendapatkan hasil berupa bentuk-bentuk kesalahan sintaksis dan leksikon dalam karangan deskripsi berbahasa Mandarin dan menjabarkan penyebab kesalahan berbahasa pada karangan deskripsi berbahasa Mandarin pada mahasiswa angkatan 2012/2013 Prodi Pendidikan Bahasa Mandarin Fakultas Bahasa dan Seni UNESA.

Hal ini sejalan dengan penelitian yang akan dilakukan yaitu dengan mengumpulkan data, mengklasifikasikan data tentang kesalahan sintaksis dan leksikon dalam karangan deskriptif berbahasa Mandarin mahasiswa angkatan 2012/2013 Prodi Pendidikan Bahasa Mandarin UNESA. Karena penelitian ini ingin mendapatkan hasil berupa bentuk-bentuk kesalahan sintaksis dan leksikon dalam karangan deskripsi berbahasa Mandarin dan menjabarkan penyebab kesalahan berbahasa pada karangan deskripsi berbahasa Mandarin pada mahasiswa angkatan 2012/2013 Prodi Pendidikan Bahasa Mandarin Fakultas Bahasa dan Seni UNESA.

Data dalam penelitian ini berupa kesalahan frasa, klausa, dan kalimat bahasa Mandarin yang terdapat dalam karangan deskriptif dan faktor-faktor penyebab kesalahan sintaksis dan leksikon yang dilakukan mahasiswa Prodi Pendidikan Bahasa Mandarin Universitas Negeri Surabaya angkatan 2012. Menurut Mahsun (2005:28) hal lain ada kaitannya dengan data adalah menyangkut sumber data, 
yang di dalamnya terdapat masalah yang berhubungan dengan populasi, sampel, dan informan.

Dalam penelitian ini metode yang digunakan adalah metode penugasan. Metode pemberian tugas merupakan salah satu metode untuk memberikan pengalaman belajar yang dapat meningkatkan cara belajar yang lebih baik dan memantapkan penguasaan perolehan hasil belajar.

Dalam penelitian ini digunakan teknik penelitian padan, yaitu teknik hubungbanding menyamakan, dan teknik hubung-banding membedakan. Menurut Mahsun (2005: 382), secara operasional, metode dan teknik ini digunakan dengan maksud menghubungbandingkan antara bentuk-bentuk yang menjadi realisasi makna tertentu dalam dua bahasa yang digunakan oleh masing-masing komunitas tutur yang menjadi sampel penelitian. Metode padan intralingual adalah metode analisis dengan cara menghubung-bandingkan unsur-unsur yang bersifat lingual, baik yang terdapat dalam satu bahasa maupun dalam beberapa bahasa yang berbeda.

Analisis data dilakukan melalui dua tahap, yaitu: (1) mencatat dan menyusun data secara numerik tentang kata, frasae, atau kalimat serta ketidaktepatan penggunaan partikel dalam bahasa Mandarin, (2) Mendeskripsikan dan membetulkan bentuk kesalahan yang ada. Kode data dalam analisis data ini adalah KSint merupakan kode untuk bentuk kesalahan sintaksis. Selanjutnya KSint/a merupakan bentuk kesalahan struktuk frasa. Kode KSint/b merupakan bentuk kesalahan sintaksis struktur klausa. Kode KSint/c merupakan kode untuk kesalahan sintaksis kesalahan penyusunan fungtor. KSint/d untuk kode dengan kesalahan penggunaan partikel. Dan terakhir adalah kesalahan penyusunan struktur kalimat yang diberi kode KSint/e. Untuk bentuk kesalahan leksikon makan akan diberikan kode (KLkn) pada bentuk kesalahan yang ada, (3) angket dan pedoman wawancara (data 2) Dalam memperoleh data yang ke-2, pertama yang dilakukan oleh peneliti dalam penelitian ini adalah menyebarkan angket yang terdiri atas beberapa 
pertanyaan dan harus diisi oleh para mahasiswa Prodi Pendidikan Bahasa Mandarin angkatan 2012. Selanjutnya teknik pengumpulan data yang digunakan dalam penelitian kualitatif lebih menekankan pada teknik wawancara, khususnya wawancara mendalam. Wawancara yang digunakan adalah wawancara kualitatif. Artinya, peneliti mengajukan pertanyaan-pertanyaan secara lebih bebas dan leluasa. Wawancara kualitatif merupakan salah satu teknik untuk mengumpulkan data dan informasi. Penggunaan metode ini didasarkan pada dua alasan. Pertama, dengan wawancara peneliti dapat menggali tidak saja apa yang diketahui dan dialami subjek yang diteliti, tetapi apa yang tersembunyi jauh di dalam diri subjek penelitian. Kedua, apa yang ditanyakan kepada informan bias mencakup hal-hal bersifat lintas waktu, yang berkaitan dengan masa lampau, masa kini, dan juga masa mendatang. Dalam penelitian ini menggunakan teknik wawancara terstruktur, yaitu model pilihan apabila pewawancara mengetahui apa yang tidak diketahuinya, dan karenanya dapat membuat kerangka pertanyaan yang tepat untuk memperolehnya. Dalam wawancara terstruktur pertanyaan ada di tangan pewawancara, dan respons terletak pada informan.

\section{Data Penelitian dan Sumber Data}

Data dalam penelitian ini berupa kesalahan frasa, klausa, dan kalimat bahasa Mandarin yang terdapat dalam karangan deskriptif dan faktor-faktor penyebab kesalahan sintaksis dan leksikon yang dilakukan mahasiswa Prodi Pendidikan Bahasa Mandarin Universitas Negeri Surabaya angkatan 2012.

\section{Sumber Data}

Menurut Mahsun (2005:28) hal lain ada kaitannya dengan data adalah menyangkut sumber data, yang di dalamnya terdapat masalah yang berhubungan dengan populasi, sampel, dan informan.

\section{Subjek Penelitian}

Dalam penelitian ini yang merupakan subjek penelitian adalah para mahasiswa Prodi Pendidikan Bahasa Manadarin Unesa 2012 A dan B. Berikut 134 | http://journal.unesa.ac.id/index.php/paramasastra 
data tabel mengenai mahasiswa Prodi Pendidikan Bahasa Mandarin Unesa 2012 A dan B. Mahasiswa Prodi Pendidikan Bahasa Mandarin Unesa 2012 A dan B total berjumlah 79 anak, dan sekarang ada 6 orang mahasiswa sedang melanjutkan pendidikan di China selama 1 tahun. Berikut nama mahasiswa yang sedang melanjutkan pendidikannya di China, Rudi Hartono, Nanda Permata, Andi, Ayuwinda, Linda Eka, Rizky Ady, Dwi Wahyuni. Sisanya terdapat mahasiswa yang tidak hadir dan ada yang mengundurkan diri dari Prodi Mandarin, sehingga jumlah subjek penelitian tersisa 53 mahasiswa.

\section{Teknik Pengumpulan Data dan Instrumen Penelitian}

Menurut Mahsun (2007: 144), daftar pertanyaan untuk bidang sintaksis biasanya berupa frasa, klausa, kalimat-kalimat, dan juga cerita-cerita pendek. Di dalam penelitian ini peneliti menggunakan metode penugasan. Penugasan yang diberikan pada penelitian ini berupa karangan deskriptif yang ditulis pada subjek penelitian.

\section{Instrumen Pengumpulan data}

Intrumen pengumpulan data 1 yang digunakan untuk penelitian ini adalah berupa tes mengarang deskriptif Mahasiswa Prodi Pendidikan Bahasa Mandarin UNESA angkatan 2012. Dalam memperoleh data yang ke-2, pertama yang dilakukan oleh peneliti dalam penelitian ini adalah menyebarkan angket yang terdiri atas beberapa pertanyaan dan harus diisi oleh para mahasiswa Prodi Pendidikan Bahasa Mandarin angkatan 2012. Selanjutnya teknik pengumpulan data yang digunakan dalam penelitian kualitatif lebih menekankan pada teknik wawancara, khususnya wawancara mendalam. Wawancara yang digunakan adalah wawancara kualitatif.

\section{Metode dan Teknik Analisis Data}

Dalam penelitian ini metode yang digunakan adalah metode penugasan. Metode pemberian tugas merupakan salah satu metode untuk memberikan pengalaman belajar yang dapat meningkatkan cara belajar yang lebih baik dan 
memantapkan penguasaan perolehan hasil belajar. Dalam menetapkan rancangan langkah-langkah pemberian tugas hendaknya dapat tercermin: 1) tugas apa yang harus dilakukan anak; 2) hasil yang diharapkan untuk mengerjakan tugas tersebut: 3) bagaimana cara mengerjakan tugas tersebut; 4) bahan dan alat apa yang diperlukan untuk menyelesaikan tugas tersebut. Jadi dalam menetapkan rancangan pemberian tugas ada beberapa langkah yang harus dilakukan guru (Moeslichatoen R, 2004:196).

\section{Langkah Analisis Data}

1) Mengumpulkan data: berupa kesalahan berbahasa yang dibuat oleh siswa, misalnya hasil ulangan, karangan, atau percakapan.

2) Mengidentifikasi dan mengklasifikasi kesalahan: mengenali dan memilahmilah kesalahan berdasarkan kategori kebahasaan, misalnya kesalahankesalahan pelafalan, pembentukan kata, penggabungan kata, penyusunan kalimat.

3) Memperingkat kesalahan: mengurutkan kesalahan berdasarkan frekuensi atau keseringannya.

4) Menjelaskan kesalahan: menggambarkan letak kesalahan, penyebab kesalahan, dan memberikan contoh benar.

5) Memprakirakan atau memprediksi daerah atau butir kebahasaan yang rawan: meramalkan tataran bahasa yang dipelajari yang potensial mendatangkan kesalahan.

6) Mengoreksi kesalahan: memperbaiki dan bila dapat menghilangkan kesalahan melalui penyusunan bahan yang tepat, buku pegangan yang baik, dan teknik pengajaran yang serasi.

\section{Teknik Analisis data}

Tahap analisis data merupakan tahap yang menentukan, karena pada tahap ini kaidah-kaidah yang mengatur keberadaan objek penelitian harus sudah diperoleh. Dalam penelitian ini digunakan teknik peneltian padan, yaitu teknik 
hubung-banding menyamakan, dan teknik hubung-banding membedakan. Menurut Mahsun (2005: 382), secara operasional, metode dan teknik ini digunakan dengan maksud menghubungbandingkan antara bentuk-bentuk yang menjadi realisasi makna tertentu dalam dua bahasa yang digunakan oleh masingmasing komunitas tutur yang menjadi sampel penelitian. Metode padan intralingual adalah metode analisis dengan cara menghubung-bandingkan unsureunsur yang bersifat lingual, baik yang terdapat dalam satu bahasa maupun dalam beberapa bahasa yang berbeda. Tujuan metode dengan teknik ini adalah untuk memilah unsur mana yang merupakan unsur asli dan mana yang merupakan hasil adaptasi linguistik, baik yang berupa adaptasi fonologi maupun yang berupa pinjaman leksikal atau gramatikal yang terdapat dalam salah satu dari kedua bahasa yang komunitas tuturnya melakukan kontak tersebut.

Analisis data dilakukan melalui dua tahap, yaitu:

1. Mencatat dan menyusun data secara numerik tentang kata, frasae, atau kalimat serta ketidaktepatan penggunaan partikel dalam bahasa Mandarin.

2. Mendeskripsikan dan membetulkan bentuk kesalahan yang ada. Kode data dalam analisis data ini adalah KSint merupakan kode untuk bentuk kesalahan sintaksis. Selanjutnya KSint/a merupakan bentuk kesalahan struktuk frasa. Kode KSint/b merupakan bentuk kesalahan sintaksis struktur klausa. Kode KSint/c merupakan kode untuk kesalahan sintaksis kesalahan penyusunan fungtor. KSint/d untuk kode dengan kesalahan penggunaan partikel. Dan terakhir adalah kesalahan penyusunan struktur kalimat yang diberi kode KSint/e. Untuk bentuk kesalahan leksikon makan akan diberikan kode (KLkn) pada bentuk kesalahan yang ada.

\section{Uji Keabsahan Data}

Untuk menguji keabsahan hasil analisis data, peneliti menggunakan teknik triangulasi, yaitu pengecekan pada sumber data dan metode. Pengecekan sumber data dilakukan dengan mewawancarai subjek penelitian. Penggunaan metode 
dalam pengumpulan data lebih dari satu, yaitu metode penugasan, metode wawancara, dan metode angket. Pengumpulan data didapat dari metode penugasan yaitu berupa tugas mengarang sebuah karangan deskripsi berbahasa Mandarin dengan ketentuan sebagai berikut: deskripsi minimal 3 paragraf, maksimal 5 paragraf, dan tiap paragraf terdiri atas 5-10 kalimat. Para subjek diberi waktu satu minggu untuk menyelesaikan tugas mengarang mereka, setelah itu dikumpulkan kepada peneliti. Setelah pebelajar mengumpulkan tugas karangan mereka, peneliti membagikan angket kepada para subjek yaitu mahasiswa angkatan 2012/2013 untuk mengetahui faktor penyebab yang pertama. Lalu peneliti melakukan tes wawancara kepada 14 orang subjek yang dimana hasil wawancara tersebut digunakan untuk mengetahui faktor penyebab kesalahan berbahasa yang kedua.

\section{PEMBAHASAN}

Berdasarkan hasil penelitian dan analisis data yang telah dilakukan, terdapat beberapa temuan-temuan yang dapat didiskusikan untuk menarik kesimpulan akhir. Semua data tersebut akan dikaitkan dengan teori-teori analisis kesalahan berbahasa. Sebelum diskusi dimulai, dalam bab ini dipaparkan beberapa temuan yang terkait dengan rumusan masalah pada bab I pendahuluan. Selanjutnya, pada sesi diskusi disajikan sesuai urutan masalah. Adapun diskusi hasil penelitian adalah sebagi berikut:

Pada diskusi hasil penelitian ini akan dipaparkan mengenai telaah hasil penelitian kesalahan sintaksis dalam karangan deskripsi berbahasa Mandarin mahasiswa prodi pendidikan bahasa Mandarin angkatan 2012 Universitas Negeri Surabaya.

\section{Kesalahan Sintaksis dan Leksikon}

Menurut科德 (Kē dé) dalam颂浩 (Sòng hào) (2007:85) 区分了三种偏误 :

系统前错误。此时, 学习者处在随机猜测状态, 对将要学习的东西只有非常 模糊的认识, 其话语大部分情况下是错误的, 运气好的时候可能会说对。 Ke 138 | http://journal.unesa.ac.id/index.php/paramasastra 
Rendy Aditya, Kesalahan Berbahasa dalam Karangan...(hlm. 128 - 145)

salahan yang terjadi akibat pebelajar belum mempelajari bahasa target. b) 系统错误。学习者开始意识到形式和功能存在联系, 并试图通过不同的假设 来发现这种联系。Kesalahan yang dilakukan pebelajar ketika mempelajari bahasa target.

系统后错误。已经发现了联系的系统性（即规则），但在表达的时候有不一 致的情况。Kesalahan yang dilakukan pebelajar setelah mempelajari bahasa target. Pebelajar telah menemukan hubungan aturan dan kesalahan yang dilakukan. Pebelajar dalam hal ini melakukan kesalahan berbahasa yang disebabkan perform yang kurang baik. Dalam hal ini pebelajar sudah menguasai tentang tata bahasa dalam bahasa target, tetapi ketika mengujarkan atau mengerjakan latihan, pebelajar tersebut melakukan kesalahan yang disebabkan oleh beberapa faktor, misalnya kelalaian pebelajar, konsentrasi yang terganggu, maupun pikiran yang sedang kacau, sehingga terjadilan kesalahan yang disebabkan performansi.

Dalam kesalahan sintaksis terdapat beberapa bentuk kesalahan yang dapat di masukan kedalam beberapa bentuk kesalahan, yaitu bentuk kesalahan penyusunan frasa, kesalahan penyusunan klausa, kesalahan penyusunan kalimat.

\section{Kesalahan Penyusunan Kalimat}

Dalam karangan yang telah ditulis oleh subjek, terdapat beberapa macam kesalahan. Berikut penjabaran dari bentuk-bentuk kesalahan dalam penyusunan kalimat yang ditulis dalam karangan deskriptif berbahasa Mandarin.

Kesalahan Penyusunan Fungtor

Kesalahan penyusunan fungtor pada kalimat. Kesalahan yang diakibatkan subjek penelitian melakukan kesalahan dalam menggunakan maupun meletakan subjek, predikat, objek maupun keterangan (tempat, waktu) dalam sebuah kalimat. 
Misalnya kalimat berikut yang merupakan contoh kalimat yang ditulis oleh subjek penelitian:

*老师们也非常全心. (KSint/c). Kalimat tersebut memiliki kesalahan berupa kekuranglengkapan susunan kalimat berupa objek kalimat, yaitu kata我们 (wo men) yang memiliki arti "kami". Dengan demikian, kalimat yang benar adalah sebagai berikut:

老师们非常爸心 (我们). Kalimat tersebut memiliki arti “para dosen juga sangat memperhatikan kami”. Dari kesalahan tersebut terdapat 5 butir kesalahan dengan prosentase $2 \%$ dari total jumlah kesalahan yang ada yaitu sebesar 228 butir kesalahan.

Kesalahan Penyusunan Partikel

Kesalahan penyususnan partikel merupakan kesalahan dalam penggunaan partikel dalam bahasa Mandarin.

*因为风景 ( 得 ) 真漂亮. (KSint/d). Dalam kalimat tersebut terdapat kesalahan dalam pengunaan partikel得 (de), karena kata得 harus terdapat kata sifat di depannya, bukan kata benda. Dengan demikian, kalimat yang benar adalah sebagai berikut: 因为风景真漂亮. Kalimat tersebut memiliki arti "karena pemandangannya sangat indah". Dari hasil penelitian tersebut, dalam hal kesalahan partikel terdapat kesalahan dengan jumlah sebanyak 9 butir kesalahan, dengan prosentase kesalahan sebanyak $4 \%$ dari jumlah total kesalahan yang ada. Hal tersebut kebanyakan dikarenakan para responden tidak menuliskan atau malah yang seharusnya tidak perlu dituliskan menjadi dituliskan.

\section{Bentuk Kesalahan Leksikon dalam Karangan Deskriptif Berbahasa Mandarin}

140 | http://journal.unesa.ac.id/index.php/paramasastra 
Dalam kesalahan berbahasa juga sering dijumpai kesalahan leksikon, yang menurut Tarigan (1988: 200), kesalahan leksikon adalah kesalahan memakai kata yang tidak atau kurang tepat. Contoh kesalahan dalam bahasa Mandarin misalnya dalam 我家 (是) 有三个卧室, dalam kalimat tersebut terdapat kesalahan penggunaan kata 是有 (shi you), karena dua kata tersebut memiliki arti “adalah" dan "mempunyai". Dua kata tersebut tidak dapat digunakan secara bersamaan. Seharusnya kata 是 (shi) dihilangkan dalam kalimat tersebut. Kalimat yang benar adalah sebagai berikut 我家有三个卧室, yang memiliki arti rumah saya mempunyai 3 buah kamar tidur.

Kesalahan terbanyak adalah pada kesalahan leksikon dengan prosentase sebesar 58\% dari total jumlah kesalahan yang ada sebesar 228 butir kesalahan, dengan jumlah kesalahan sebanyak 133 butir kesalahan. Dari jumlah tersebut dapat diketahui bahwa 53 responden yaitu mahasiswa Unesa Prodi Pendidikan Bahasa Mandarin masih mengalami kesulitan untuk penggunaan kata yang ada dalam bahasa Mandarin. Meskipun mereka sudah sekitar 3 tahun mempelajari bahasa Mandarin. Hal ini didukung oleh hasil angket pada pertanyaan ke 7 dan 8 . Yang pertama adalah bentuk kesalahan dalam hal penggunaan kata, dan hasilnya adalah sebanyak 46 siswa menjawab bentuk kesalahan fungsi penggunaan kata. Sebanyak 46 orang responden menjawab bahwa hal tersebut disebabkan karena responden kurang memahami fungsi kata tersebut, sehingga banyak dari mereka yang melakukan kesalahan penggunaan kata dalam karangan deskriptif tersebut. Yang kedua adalah kesalahan tata bahasa, yaitu sebesar 34\% dari total jumlah kesalahan yang ada yaitu sebesar 243 butir kesalahan. Dengan jumlah total kesalahan tata bahasa sebanyak 82 butir.

\section{Faktor Penyebab Kesalahan}

http://journal.unesa.ac.id/index.php/paramasastra | 141 
Dari hasil angket dan wawancana yang telah peneliti lakukan, yang telah dilakukan oleh peneliti, yang pertama adalah dari hasil mengisi angket banyak dari responden yang merasa ketika mempelajari bahasa Mandarin, hal yang paling sulit dipelajari adalah tata bahasa dan pelafalan kata dalam bahasa Mandarin. Hal ini dibuktikan dengan jumlah responden yang menjawab tata bahasa merupakan pelajaran yang paling sulit dipelajari dengan jumlah responden sebanyak 8 orang. Lalu ada pelafalan nada dan kata degan responden yang menjawab sebanyak 7 orang. Dan yang terakhir ada 3 orang responden yang menjawab hal yang sulit dipelajari dalam bahasa Mandarin adalah dalam bidang penulisan huruf Mandarin. 8 orang dari 14 orang dari para responden yang tidak dapat memberikan contoh kalimat dalam beberapa bentuk kalimat. Adapun responden yang memberikan contoh kalimat dalam beberapa bentuk kalimat tetapi contoh kalimat tersebut salah atau tidak sesuai dengan bentuk kalimat yang dimaksud. Selain itu penyebab kesalahan yang terjadi juga disebabkan oleh sistem bahasa Mandarin sendiri yang mempunyai tingkat kesulitan tertentu yang menjadikan pebelajar bahasa Mandarin mengalami kesalahan. Bahasa Mandarin memiliki tulisan berupa karakter atau symbol yang berbeda dengan bahasa Indonesia. Hal tersebut juga dapat menjadi sebuah kesulitan tersendiri bagi pebelajar bahasa Mandarin. Karena karakter atau simbol tersebut tidak dapat memiliki goresan yang kurang ataupun lebih, karena dapat memiliki arti yang salah. Selain itu dalam bahasa Mandarin juga terdapat nada yang dilafalkan yang berbeda dengan bahasa Indonesia. Jika pebelajar bahasa Mandarin menyebutkan sebuah kata dengan nada yang berbeda, maka kata tersebut dapat memiliki arti yang berbeda.

\section{SIMPULAN}

Berdasarkan hasil pembahasan dan diskusi dari penelitian kesalahan sintaksis dalam karangan deskripsi berbahasa Mandarin mahasiswa angkatan 2012/2013 Prodi Pendidikan bahasa Mandarin Universitas Negeri Surabaya dapat disimpulkan sebagai berikut: (1) dari bentuk kesalahan sintaktis ditemukan tiga jenis kesalahan. Yang pertama adalah bentuk kesalahan sintaksis dalam hal tata 142 | http://journal.unesa.ac.id/index.php/paramasastra 
bahasa bahasa Mandarin, yaitu sejumlah 81 butir kesalahan. Selanjutnya adalah bentuk kesalahan penggunan partikel dalam bahasa Mandarin yang tidak tepat, sejumlah 9 butir kesalahan dan yang tersedikit adalah berupa kesalahan penyusunan fungtor kalimat yaitu sebanyak 5 butir kesalahan, (2) dari bentuk kesalahan leksikon dalam karangan deskripsi berbahasa Mandarin mahasiswa angkatan 2012/2013 Prodi Pendidikan Bahasa Mandarin UNESA ditemukan kesalahan leksikon yang tidak tepat, sejumlah 133 butir kesalahan, (3) dari hasil angket dan wawancara untuk mengetahui faktor yang menyebabkan kesalahan sintaktis dan leksikon pada karangan deskripsi mahasiswa Prodi Pendidikan Bahasa Mandarin UNESA angkatan 2012/2013 adalah faktor kekurangpahaman siswa terhadap penggunaan kata dalam bahasa Mandarin, dan kekurangpahaman siswa terhadap tata bahasa dalam bahasa Mandarin.

Sebagaiamana hasil penelitian ini, disarankan hasil tersebut dapat digunakan untuk pembelajaran BM, terutama mata kuliah BM Komprehensif dan BM menulis. Hasil penelitian ini bersifat teknis dan merupakan hasil satu dari sekian banyak penelitian mengenai analisis kesalahan berbahasa yang ada. Oleh karena itu, pembaca diharapkan dapat membandingkan terlebih dahulu dengan hasil penelitian yang lainnya, agar dapat mengambil hasil penelitian tersebut.

Dalam bidang pembelajaran, hasil penelitian tersebut juga dapat menjadi acuan penyusunan materi pembelajaran Bahasa Mandarin. Hasil penelitian ini diharapkan pebelajar BM dapat mengidentifikasi bentuk-bentuk kesalahan dalam penggunaan kata, penulisan huruf, pemilihan kata, dan tata bahasa bahasa Mandarin.

\section{DAFTAR RUJUKAN}

Aliah Yoce. 2014. Analisis Wacana Kritis. Bandung: Refika Aditama.

Arikunto, Suharsimi. 2010. Prosedur Penelitian: Suatu Pendekatan Praktik. Yogyakarta: PT RinekaCipta 
Finoza, Lamuddin. 2004. Komposisi Bahasa Indonesia. Jakarta: DWADASA SARANA BERSAMA.

Ghufron dan Iib. 2013. Sintaksis Bahasa Indonesia. Surabaya: CV. Istana.

Mahsun. 2005. Metode Penelitian Bahasa. Jakarta: Radja Grafindo Persada.

Moleong, Lexy J. 2011. Metodologi Penelitian Kualitatif. Bandung: Remaja Rosdakarya.

Keraf, Gorys. 1997. Tata Bahasa Rujukan Bahasa Indonesia. Jakarta: Grasindo.

Kridalaksana, Harimurti. 1984. Kamus Linguistik. Edisi ke-2 Cetakan pertama. Jakarta: PT. Gramedia.

Lapoliwa, Hans. 1990. Klausa Pemerlengkapan Dalam Bahasa Indonesia. Yogyakarta: KANISIUS.

Liberty dan Djoko. 2005. Pesona Bahasa .Jakarta: Gramedia Pustaka Utama.

Mia, Ong. 2014. Pengantar Linguistik Bahasa Tionghoa. Surabaya: Perwira Media Nusantara.

Moeslichatoen. 2004. Metode Pengajaran di Taman Kanak-Kanak. Jakarta: Rineka Cipta.

Pateda, Mansoer. 1989. Analisis Kesalahan Bahasa. Flores: Nusa Indah.

Putrayasa, Ida Bagus. 2006. Tata Kalimat Bahasa Indonesia. Bandung: Refika Aditama.

Putrayasa, Ida Bagus. 2007. Analisis Kalimat. Bandung: PT Refika Aditama.

Ramlan, M. 1996. Sintaksis. Yogyakarta: CV. Karyono.

Rani, Abdul Dkk. 2004. Analisis Wacana. Jakarta: Bayumedia.

Satori, Djam'an dan Aan Komariah. 2010. Metodologi Penelitian Kualitatif. Bandung: ALFABETA.

Suhardi. 2013. Dasar-Dasar Ilmu Sintaksis Bahasa Indonesia. Jogjakarta: ARRUZZ MEDIA.

Sugiyono. 2008. Memahami Penelitian Kualitatif. Bandung: ALFABETA.

Tarigan, Henry Guntur. 2009. Pengajaran Sintaksis. Bandung: ANGKASA.

144 | http://journal.unesa.ac.id/index.php/paramasastra 
Rendy Aditya, Kesalahan Berbahasa dalam Karangan...(hlm. 128 - 145)

Tarigan, Henry Guntur. 1988. Pengajaran Analisis Kesalahan Berbahasa. Bandung: ANGKASA.

Oktavianus. 2006. Analisis Wacana Lintas Bahasa. Padang: Andalas University Press.

Verhaar, J. W. M. 2010. Asas-asas Linguistik Umum. Yogyakarta: Gadja Mada University Press.

周小兵. 2009. 对外汉语教学入门.广州: 中山大学出版社.

陆庆和. 2006. 实用对外汉语教学语法. 北京: 北京大学出版社.

季小兵. 2014. 初中生作文一本全. 北京: 首都师范大学出版发行.

刘颂浩. 2007. 第二语言习得导论. 北京: 世界图书出版公司北京公司.

王建勤. 2009. 第二语言习得研究. 北京: 高务印书馆出版.

增订本. 2010. 实用现代汉语语法.北京: 商务印书馆.

黄伯荣. 2002. 现代汉语. 北京: 高等教育.

蒋严. 1998. 语用推理与“都”的句法 / 语义特征,Jurnal,

http://www.cbs.polyu.edu.hk/ctyjiang/file/douweb.htm

薛笑从. 2002. 英汉被动句的互译方法,Jurnal, http://wenku.baidu.com/link?url=KW91xEuitaOW2KKghiiRYm9sRk1lNV v2YheZzTDUZ1bIJwrb6KMpyBWH1GcgihdXcSXhW2mltLaRjPKJs1S9T ulA5E3Sz4UH5mrUGvdf-kK

Advertorial. 2014. "Enam Alasan Kuliah di China”. Kompas. 19 April 2014. http://edukasi.kompas.com/read/2014/04/19/2017508/Enam.Alasan.Kuliah. di.Tiongkok?utm_campaign=related\&utm_medium=bpkompas\&utm_source=news\& . Diakses pada kamis 15 Oktober 2015.

Advertorial. 2010. "Tiga Daya Tarik Kuliah ke China”. Kompas. 29 November 2010.http://edukasi.kompas.com/read/2010/11/29/15310189/Tiga.Daya.Tari k.Kuliah.ke.China. Diakses pada kamis 15 Oktober 2015 